\title{
Effect of Total Mixed Ration Composition on Fermentation and Efficiency of Ruminal Microbial Crude Protein Synthesis In Vitro
}

\author{
J. Boguhn, H. Kluth, and M. Rodehutscord ${ }^{1}$ \\ Institut für Ernährungswissenschaften, Martin-Luther-Universität Halle-Wittenberg, 06099 Halle (Saale), Germany
}

\begin{abstract}
The goal of this study was to identify dietary factors that affect fermentation and efficiency of microbial crude protein $\left(\mathrm{CP}_{\mathrm{M}}\right)$ synthesis in the rumen in vitro. We used 16 total mixed, dairy cow rations with known digestibilities that varied in ingredient composition and nutrient content. Each ration was incubated in a Rusitec $(\mathrm{n}=3)$ for $15 \mathrm{~d}$, and fermentation of different fractions was assessed. Observed extents of fermentation in $24 \mathrm{~h}$ were 35 to $47 \%$ for organic matter, 25 to $60 \%$ for crude protein, 3 to $28 \%$ for neutral detergent fiber, and 31 to $45 \%$ for gross energy. Organic matter fermentation depended on the content of crude protein and neutral detergent fiber in the ration. We studied net synthesis of $\mathrm{CP}_{\mathrm{M}}$ using an ${ }^{15} \mathrm{~N}$ dilution technique and found that $7 \mathrm{~d}$ of continuous ${ }^{15} \mathrm{~N}$ application are needed to achieve an ${ }^{15} \mathrm{~N}$ enrichment plateau in the $\mathrm{N}$ of isolated microbes in this type of study. The efficiency of $\mathrm{CP}_{\mathrm{M}}$ synthesis was 141 to $286 \mathrm{~g} / \mathrm{kg}$ of fermented organic matter or 4.9 to $11.1 \mathrm{~g} / \mathrm{MJ}$ of metabolizable energy, and these ranges agree with those found in the literature. Multiple regressions to predict the efficiency of $\mathrm{CP}_{\mathrm{M}}$ synthesis by diet data showed that crude protein was the only dietary chemical fraction that had a significant effect. Fat content and the inclusion rate of corn silage in the ration also tended to improve efficiency. We suggest that microbial need for preformed amino acids may explain the crude protein effect. A large part of the variation in efficiency of microbial activity still remains unexplained.
\end{abstract}

Key words: Rusitec, fermentation, efficiency, microbial yield

\section{INTRODUCTION}

The amount of microbial $\mathbf{C P}\left(\mathbf{C P}_{\mathbf{M}}\right)$ synthesized in the rumen plays a major role in providing the cow with amino acids for milk synthesis. Because fermentable energy limits $\mathrm{CP}_{\mathrm{M}}$ synthesis (Hoover and Stokes, 1991)

Received April 15, 2005.

Accepted November 11, 2005.

${ }^{1}$ Corresponding author: markus.rodehutscord@landw.uni-halle.de and protein supply at the duodenum may limit milk protein synthesis (Clark, 1975; Wright et al., 1998), the prediction of the efficiency of $\mathrm{CP}_{\mathrm{M}}$ synthesis is of value for feeding high-yielding dairy cows. If dietary factors were known to alter $\mathrm{CP}_{\mathrm{M}}$ synthesis in the rumen, they could be used to influence or to predict microbial yield.

The mean of 69 observations reviewed by Stern and Hoover (1979) indicates that $169 \mathrm{~g}$ of $\mathrm{CP}_{\mathrm{M}} / \mathrm{kg}$ of apparently digested $\mathrm{OM}$ is synthesized with a range from 63 to $307 \mathrm{~g}$. The efficiency of $\mathrm{CP}_{\mathrm{M}}$ synthesis, determined with cannulated cows, is about $10.1 \mathrm{~g}$ of $\mathrm{CP}_{\mathrm{M}} / \mathrm{MJ}$ of $\mathrm{ME}$ $(\mathrm{SD}=1.5 \mathrm{~g})$ and $156 \mathrm{~g}$ of $\mathrm{CP}_{\mathrm{M}} / \mathrm{kg}$ of digestible $\mathrm{OM}(\mathrm{SD}=$ $24 \mathrm{~g}$ ), respectively, based on a recent review (Gesellschaft für Ernährungsphysiologie, 2001). In vitro investigations have shown similar results (Stokes et al., 1991; Bach et al., 1999).

Reasons for this wide range may originate from the methods of determination of $\mathrm{CP}_{\mathrm{M}}$ (Stern and Hoover, 1979), the supply of energy and nitrogen (Veira et al., 1980; Kang-Meznarich and Broderick, 1981; Madsen and Hvelplund, 1988) and its synchronization (HerreraSaldana et al., 1990; Aldrich et al., 1993; Sinclair et al., 1993), the availability of $\mathrm{N}$ (Siddons et al., 1985; Kajikawa et al., 2002), the supply of P (Petri et al., 1988), the feedstuffs (Hristov and Broderick, 1996; Sutton et al., 2000; Younge et al., 2004), or the management of feeding (Chamberlain and Thomas, 1979; Verbiè et al., 1999). The amount of fermentable OM is a dominant factor influencing $\mathrm{CP}_{\mathrm{M}}$ synthesis in the rumen because it depends on the availability of $\mathrm{N}$ and carbohydrates (NRC, 2001).

The association between high levels of DMI and high amounts of concentrates has raised interest in feeding TMR to dairy cows. Such rations offer the opportunity to stabilize highly efficient ruminal digestion (Coenen, 1996), but systematic studies on factors that determine the efficiency of $\mathrm{CP}_{\mathrm{M}}$ synthesis with TMR feeding have not been reported.

The purpose of this study was to determine the extent of fermentation of different nutrients from TMR and to derive equations that allow for an identification of factors influencing efficiency of $\mathrm{CP}_{\mathrm{M}}$ synthesis. When such prediction equations are to be calculated mathematically, many data are generally needed, as is also 
Table 1. Composition of the 16 TMR (\% of DM)

\begin{tabular}{|c|c|c|c|c|c|c|c|c|c|c|c|c|c|c|c|c|}
\hline \multirow[b]{2}{*}{ Ingredient } & \multicolumn{16}{|c|}{ TMR } \\
\hline & $\mathrm{A}^{1}$ & $\mathrm{~B}^{1,2}$ & $\mathrm{C}$ & $\mathrm{D}$ & $\mathrm{E}$ & $\mathrm{F}$ & G & $\mathrm{H}$ & I & $\mathrm{J}$ & $\mathrm{K}^{3}$ & $\mathrm{~L}^{3}$ & M & $\mathrm{N}$ & $\mathrm{O}$ & $\mathrm{P}^{3}$ \\
\hline Corn silage & 25.0 & 24.0 & 42.2 & 36.9 & 24.7 & & 33.0 & 53.8 & 20.5 & 10.1 & 19.0 & 19.0 & 13.1 & 16.6 & 45.6 & 40.0 \\
\hline Beet pulp silage & & & 4.7 & 6.8 & & & & & 6.1 & 6.0 & & & & & & \\
\hline Alfalfa silage & & & & & 13.6 & & & & 14.0 & & & 29.0 & & & & \\
\hline Corn cob silage & 17.0 & 17.0 & & & & & & & & & 20.0 & 20.0 & & & & 10.0 \\
\hline Brewers grains silage & 7.0 & 7.0 & & & & 7.0 & & & & & 4.0 & 4.0 & & & & 8.0 \\
\hline Soybean meal $(\mathrm{SBM})^{4}$ & 16.0 & & & & & & & & & 19.1 & & & & 23.1 & & \\
\hline Rapeseed meal (RSM) $)^{4}$ & & 17.0 & & & & & & & & 3.5 & 4.0 & 4.0 & & & & 10.0 \\
\hline SBM and RSM (protected) & & & & & & & & & & & 12.0 & 10.0 & & & & 8.0 \\
\hline Peas & & & & & & & 11.4 & 18.3 & & & & & & & & \\
\hline Farm $\operatorname{mix}^{5}$ & & & 41.9 & 43.3 & & & & & & & & & & & & \\
\hline
\end{tabular}

${ }^{1}$ Additional ingredient: $3 \%$ mineral and vitamin premix and propyleneglycol.

${ }^{2}$ Additional ingredient: $1 \%$ protected fat.

${ }^{3}$ Additional ingredient: $1.0 \%$ mineral and vitamin premix.

${ }^{4}$ Solvent extracted.

${ }^{5}$ Fish meal, corn, palm cake, rapeseed meal, soybean meal, barley, fat (protected), mineral and vitamin premix, and propyleneglycol.

a wide range in nutrient content. Such a data set, including $\mathrm{CP}_{\mathrm{M}}$ synthesis, is difficult to obtain with dairy cows because these studies depend on cannulated cows and are prohibitively costly. In vitro methods provide an easier, less costly way to describe fundamental processes of rumen physiology and to define precisely the conditions used in experiments (Czerkawski and Breckenridge, 1985).

\section{MATERIALS AND METHODS}

\section{Description and Preparation of Diets}

Sixteen TMR were used (Table 1). They were composed to represent rations that are typical for the German feedstuff basis for dairy cows in different stages of lactation. Each TMR contained at least one silage. Corn silage, grass silage, or both were components in 15 of the 16 TMR. Silages from beet pulp, alfalfa, moist ensiled corn, and brewers' grains also were included. In most diets, the concentrates were barley or solventextracted meals from soybean and rapeseed. Two TMR contained peas. Ingredients were individually weighed into plastic bags, mixed, and stored at $-18^{\circ} \mathrm{C}$ until further handling. Before the beginning of the experiment, the TMR were thawed, dried at $65^{\circ} \mathrm{C}$ for $24 \mathrm{~h}$, and ground through a sieve with 1-mm pore size in a hammer mill.

The TMR showed a large variation in analyzed nutrient concentrations (Table 2). The concentrations ( $\mathrm{g} / \mathrm{kg}$ of DM) were from 874 to 947 for OM, 123 to 213 for CP, 159 to 282 for crude fiber, and 20.3 to 47.6 for ether extract. The NDF and ADF concentrations ranged from 290 to 552 and 163 to $314 \mathrm{~g} / \mathrm{kg}$ of DM, respectively. All rations had been previously investigated for nutrient digestibility (Boguhn et al., 2003; Bulang et al., 2004; Kluth et al., 2005) using wether sheep according to the standard method applied in Germany (Ausschuss für Bedarfsnormen, 1991). The energy value as calculated from digestible crude nutrients according to Gesellschaft für Ernährungsphysiologie (1995) ranged from 8.2 to $11.9 \mathrm{MJ} / \mathrm{kg}$ of $\mathrm{DM}$ for $\mathrm{ME}$ and from 4.8 to $7.4 \mathrm{MJ} /$ $\mathrm{kg}$ of DM for $\mathrm{NE}_{\mathrm{L}}$ (calculated according to van Es, 1978).

\section{Experimental Procedure}

The inocula for starting the incubation were obtained from 4 rumen-cannulated sheep (Schwarzköpfiges Fleischschaf). Rumen contents from all sheep were mixed and filtered through 2 layers of linen cloth. Sheep had been fed grass hay ad libitum and an additional $200 \mathrm{~g}$ of a concentrate mix and $10 \mathrm{~g}$ of a mineral mix/ d. Alterations in the fermentation behavior were intentionally minimized by using the same ingredients over time and by using mixes from the donor animals.

The apparatus used was a modified rumen simulation technique (Rusitec) described by Czerkawski and Breckenridge (1977) in which 6 reaction vessels had a capacity of $800 \mathrm{~mL}$ each. Three vessels were used per ration. Each feed container inside the vessel contained 2 nylon bags $(\sim 100 \times 50 \mathrm{~mm}$, pore size $=100 \mu \mathrm{m}$, Fa. Linker Industrie-Technik GmbH, Kassel, Germany) filled with $15.0 \mathrm{~g}$ of the TMR that had been dried for $24 \mathrm{~h}$ at $65^{\circ} \mathrm{C}$. At 24 -h intervals, one bag was replaced with a new one so that each bag was incubated for 48 h. At the start of the system for the first $24 \mathrm{~h}$, one bag was filled with pooled rumen solids ( $\sim 60 \mathrm{~g})$ instead of 
Table 2. Chemical analysis of the 16 TMR (DM, g/kg; nutrients and detergent fibers, g/kg of DM) and energy value calculated from digestible crude nutrients $(\mathrm{MJ} / \mathrm{kg}$ of $\mathrm{DM})$

\begin{tabular}{|c|c|c|c|c|c|c|c|c|c|c|}
\hline TMR & $\mathrm{DM}_{\text {original }}{ }^{1}$ & $\mathrm{DM}_{\mathrm{dry}}{ }^{2}$ & $\mathrm{OM}$ & $\mathrm{CP}$ & $\begin{array}{l}\text { Crude } \\
\text { fiber }\end{array}$ & $\begin{array}{l}\text { Ether } \\
\text { extract }\end{array}$ & NDF & $\mathrm{ADF}$ & $\mathrm{ME}^{3}$ & $\mathrm{NE}_{\mathrm{L}}{ }^{3}$ \\
\hline A & 439 & 937 & 933 & 186 & 171 & 20.3 & 305 & 163 & 11.8 & 7.3 \\
\hline B & 438 & 932 & 937 & 162 & 175 & 30.6 & 332 & 185 & 11.5 & 7.0 \\
\hline $\mathrm{C}$ & 485 & 925 & 914 & 195 & 168 & 37.8 & 314 & 188 & 11.5 & 7.1 \\
\hline D & 445 & 932 & 918 & 200 & 164 & 37.5 & 316 & 206 & 11.6 & 7.1 \\
\hline $\mathrm{E}$ & 384 & 947 & 928 & 123 & 257 & 35.9 & 456 & 267 & 9.6 & 5.7 \\
\hline $\mathrm{F}$ & 352 & 945 & 886 & 174 & 282 & 47.6 & 497 & 289 & 10.7 & 6.4 \\
\hline G & 379 & 926 & 893 & 179 & 233 & 41.0 & 373 & 233 & 11.4 & 7.0 \\
\hline $\mathrm{H}$ & 346 & 956 & 928 & 134 & 233 & 39.8 & 364 & 224 & 11.5 & 7.1 \\
\hline I & 364 & 954 & 933 & 128 & 271 & 26.7 & 461 & 280 & 9.7 & 5.8 \\
\hline$J$ & 314 & 942 & 921 & 150 & 239 & 30.2 & 406 & 237 & 11.4 & 7.0 \\
\hline K & 448 & 941 & 935 & 172 & 179 & 40.4 & 344 & 198 & 11.8 & 7.2 \\
\hline $\mathrm{L}$ & 459 & 934 & 938 & 182 & 187 & 37.0 & 335 & 217 & 11.2 & 6.8 \\
\hline M & 385 & 942 & 874 & 166 & 243 & 25.4 & 552 & 314 & 8.2 & 4.8 \\
\hline $\mathrm{N}$ & 448 & 947 & 903 & 213 & 159 & 26.4 & 290 & 178 & 11.9 & 7.4 \\
\hline $\mathrm{O}$ & 366 & 944 & 903 & 137 & 249 & 36.5 & 476 & 283 & 9.6 & 5.7 \\
\hline $\mathrm{P}$ & 419 & 950 & 947 & 160 & 172 & 40.0 & 369 & 198 & 11.7 & 7.1 \\
\hline Mean & 404 & 941 & 918 & 166 & 211 & 34.6 & 387 & 229 & 11.0 & 6.6 \\
\hline Minimum & 314 & 925 & 874 & 123 & 159 & 20.3 & 290 & 163 & 8.2 & 4.8 \\
\hline Maximum & 485 & 956 & 947 & 213 & 282 & 47.6 & 552 & 314 & 11.9 & 7.4 \\
\hline
\end{tabular}

TMR. We mixed $400 \mathrm{~mL}$ each of strained rumen fluid and artificial saliva (McDougall, 1948) and placed the mixture into each reaction vessel initially. Artificial saliva was continuously infused at a rate of approximately $600 \mathrm{~mL} / \mathrm{d}$ using an 8-channel peristaltic pump (Ole Dich Instrumentmakers ApS, Denmark). Vertical movement of the feed containers was ensured by an electric motor with 10 to 12 strokes/min. The effluent was collected in 1-L glass bottles standing inside an ice-cold water bath.

For determination of $\mathrm{CP}_{\mathrm{M}}$ synthesis, ${ }^{15} \mathrm{~N}$ was used as a tracer for labeling the microbial fraction. Artificial saliva contained $0.7 \mathrm{mmol}$ of $\mathrm{NH}_{4}^{+} / \mathrm{L}$ from $\mathrm{NH}_{4} \mathrm{Cl}$ with a declared ${ }^{15} \mathrm{~N}$ excess of 10 atom\% (Chemotrade Chemiehandelsgesellschaft mbH Leipzig, Germany).

The removed bags containing the feed residue were washed with $2 \times 40 \mathrm{~mL}$ of artificial saliva and squeezed moderately; the liquid was then returned to its respective vessel. The feed residues were dried at $65^{\circ} \mathrm{C}$ for $24 \mathrm{~h}$.

\section{Sampling, Preparation, and Analyses}

An 8-d period of collecting samples of the feed residues, the liquid effluent, and the microbes followed a 7-d period of adaptation. As determined during the course of the study, this adaptation was necessary to achieve a plateau in ${ }^{15} \mathrm{~N}$ enrichment of microbes isolated from liquid effluent. To describe the dynamic of ${ }^{15} \mathrm{~N}$ enrichment, samples of microbes were isolated for 2 TMR (O and P; Table 1) on each day of incubation starting on d 1. Samples of the liquid effluent (320 $\mathrm{mL}$ ) were taken daily, and the reference microbes were isolated by differential centrifugation according to Brandt and Rohr (1981; Suprafuge 22, Heraeus Instruments, Hanau, Germany). In brief, the suspension was centrifuged twice at $2,000 \times g$ at $4^{\circ} \mathrm{C}$ for $5 \mathrm{~min}$. Subsequently, the supernatant was centrifuged 3 times at $27,000 \times g$ at $4^{\circ} \mathrm{C}$ for $15 \mathrm{~min}$. In between, the microbes were resuspended with a saline solution $(0.9 \% \mathrm{wt} / \mathrm{vol})$. After the last centrifugation, the microbes were frozen at $-18^{\circ} \mathrm{C}$, freeze-dried, and crushed with pestle and mortar. For all other TMR, the microbes were isolated in the same way only in the period between $\mathrm{d} 7$ to 15 .

Microbes that were attached to the feed [solid-associated microbes (SAM)] were separated from the feed residues contained in the 2 nylon bags at the termination of the study, based on Minato and Suto (1978) and according to the method described by Carro and Miller (2002). The SAM were separated from the remaining fluid and further treated as described for the reference microbes.

The ${ }^{15} \mathrm{~N}$ enrichment of $\mathrm{N}$ in dry samples from $\mathrm{NH}_{4} \mathrm{Cl}$, feed residues, effluents, and isolated microbes was measured by emission spectrometry (NOI 7, Fischer Analysen Instrumente GmbH, Leipzig, Germany) after combustion in a coupled C/N analyzer (Vario EL, Elementar Analysensysteme GmbH, Hanau, Germany). To obtain a sufficiently high amount of $\mathrm{N}$ for the ${ }^{15} \mathrm{~N}$ analysis, $\sim 1.0 \mathrm{mg}$ of $\mathrm{NH}_{4} \mathrm{Cl}, 15$ to $30 \mathrm{mg}$ of feed residues, and 2 to $5 \mathrm{mg}$ of microbes were exactly weighed into tin capsules and made airtight prior to combustion. Thirty 
milliliters of effluent was taken, and ammonia $\mathrm{N}$ was transferred into a sulfuric acid solution via $\mathrm{NaOH}$. This solution was then desiccated by lyophilization, and up to $50 \mathrm{mg}$ of the dry residue was weighed into the tin capsules for combustion. The amount of effluent $\mathrm{N}$ obtained this way was not sufficient to reliably measure the ${ }^{15} \mathrm{~N}$ enrichment in this fraction for TMR A, B, and D.

The pooled samples of feed and feed residues were analyzed for DM, ash, CP, crude fiber, NDF, and ADF according to the official methods in Germany (Naumann and Bassler, 1976). The gross energy was measured by a bomb calorimeter (C7000, Janka \& Kunkel IKA, Analysentechnik). Nitrogen content in the liquid effluent after centrifugation was determined by a Kjeltec auto 1030 analyzer from Tecator AB (Höganäs, Sweden) without a preceding hydrolysis.

\section{Calculations}

The extent of fermentation of crude nutrients, NDF, $\mathrm{ADF}$, or gross energy $\left(\mathrm{F}_{\mathrm{x}} ; \%\right)$ was determined as

$$
\mathrm{F}_{\mathrm{x}}=\frac{\text { input of } \mathrm{x}-\text { output of } \mathrm{x}}{\text { input of } \mathrm{x}} \times 100 \%
$$

where

input of $\mathrm{x}=$ input in the vessel with feed $(\mathrm{g} / \mathrm{d})$, and output of $\mathrm{x}=$ output from the vessel with feed residue $(\mathrm{g} / \mathrm{d})$.

Fermentation of OM was also calculated after correction for $\mathrm{OM}$ originating from microbes attached to the feed residues. First, the amount of $\mathrm{N}$ originating from SAM $\left[\mathrm{N}_{\mathrm{SAM}}(\mathrm{g} / \mathrm{d})\right]$ was calculated as

$$
\mathrm{N}_{\mathrm{SAM}}=\frac{{ }^{15} \mathrm{~N}_{\mathrm{FR}} \times \mathrm{N}_{\mathrm{FR}}}{{ }^{15} \mathrm{~N}_{\mathrm{SAM}}}
$$

where

${ }^{15} \mathrm{~N}_{\mathrm{FR}}={ }^{15} \mathrm{~N}$ enrichment determined in feed residues (\%),

$\mathrm{N}_{\mathrm{FR}}=$ amount of $\mathrm{N}$ in feed residues $(\mathrm{g} / \mathrm{d})$, and

${ }^{15} \mathrm{~N}_{\mathrm{SAM}}={ }^{15} \mathrm{~N}$ enrichment in $\mathrm{N}$ of the SAM (\%).

Second, the amount of OM originating from SAM in the feed residue $\left(\mathrm{OM}_{\mathrm{SAM}} ; \mathrm{g} / \mathrm{d}\right)$ was calculated as

$$
\mathrm{OM}_{\mathrm{SAM}}=\frac{\mathrm{N}_{\mathrm{SAM}}}{\mathrm{N}} \times(100-12)-0.93
$$

where
$\mathrm{N}_{\mathrm{SAM}}=\mathrm{N}$ originating from SAM (Equation $2 ; \mathrm{g} / \mathrm{d}$ ),

$\mathrm{N}=$ analyzed $\mathrm{N}$ content of SAM (\%) on an as-is basis,

$12=$ analyzed concentration of ash in SAM (\%), and

$0.93=$ analyzed proportion of DM in the isolated SAM fraction.

Because of a small sample size, DM and ash content of SAM were analyzed in pooled samples of this fraction only.

The amount of microbial $\mathrm{N}\left(\mathrm{N}_{\mathrm{M}}\right.$ in $\left.\mathrm{mg} / \mathrm{d}\right)$ leaving the vessel with effluent was calculated as

$$
\mathrm{N}_{\mathrm{M}}=\frac{{ }^{15} \mathrm{~N}_{\text {in }}-{ }^{15} \mathrm{~N}_{\text {out }}}{{ }^{15} \mathrm{~N}_{\text {Plateau }}}
$$

where

${ }^{15} \mathrm{~N}_{\text {in }}={ }^{15} \mathrm{~N}$ amounts introduced into the vessel with buffer solution (calculated on the basis of daily buffer flow and analyzed ${ }^{15} \mathrm{~N}$ content in $\mathrm{NH}_{4} \mathrm{Cl}$ ) and feed (assuming natural abundance $=0.3663 \%$ of total $\mathrm{N}$; $\mu \mathrm{g} / \mathrm{d})$,

${ }^{15} \mathrm{~N}_{\text {out }}={ }^{15} \mathrm{~N}$ amounts leaving the vessel with liquid effluent and feed residues (except ${ }^{15} \mathrm{~N}$ in reference microbes; $\mu \mathrm{g} / \mathrm{d}$ ), and

${ }^{15} \mathrm{~N}_{\text {Plateau }}={ }^{15} \mathrm{~N}$ in total $\mathrm{N}$ of the isolated reference microbes between $\mathrm{d} 7$ and 15 ( $\mu$ g of ${ }^{15} \mathrm{~N} / \mathrm{mg}$ of $\mathrm{N}$ ).

The amount of $\mathrm{CP}_{\mathrm{M}}(\mathrm{mg} / \mathrm{d})$ was calculated as $\mathrm{N}_{\mathrm{M}} \times 6.25$.

To describe the dynamics of ${ }^{15} \mathrm{~N}$ enrichment in the microbial $\mathrm{N}$ fraction in the 2 experiments with continuous sampling of microbes, the following equation (GraphPad Prism 4.02 for Windows) was used:

$$
\mathrm{y}=\mathrm{a}+\frac{(\mathrm{b}-\mathrm{a})}{\left(1+10^{\left(\left(\log _{50} \mathrm{e}^{\mathrm{c}}-\mathrm{x}\right) \times \mathrm{s}\right)}\right)}
$$

where

$\mathrm{y}={ }^{15} \mathrm{~N}$ enrichment at given $\mathrm{x}(\%)$,

$\mathrm{x}=$ time after onset of ${ }^{15} \mathrm{~N}$ administration via the artificial saliva (d),

$\mathrm{a}=$ minimum level of ${ }^{15} \mathrm{~N}$ enrichment (\%),

$\mathrm{b}=$ plateau of ${ }^{15} \mathrm{~N}$ enrichment (\%),

$\mathrm{c}=$ one-half of the plateau value of ${ }^{15} \mathrm{~N}$ enrichment $(\%)$, and

$\mathrm{s}=$ maximum slope. 
In this equation, the expression $\log _{50} \mathrm{e}^{\mathrm{c}}$ describes the time needed to achieve one-half of the plateau response in ${ }^{15} \mathrm{~N}$ enrichment.

The software package SAS for Windows (version 8.2, 1999-2001, SAS Inst., Inc., Cary, NC) was used for the statistical analysis. Multiple linear regressions were calculated with Proc Reg to identify factors that might influence $\mathrm{CP}_{\mathrm{M}}$ synthesis in the rumen. Dietary concentrations of $\mathrm{OM}, \mathrm{CP}$, crude fiber, and ether extract, as well as inclusion rates of both corn and grass silage, were considered as variables with the aim of minimizing the average coefficient of variation. As a measure of the contribution of each regressor, the $P$ values of partial correlation $\left(\boldsymbol{P}_{\boldsymbol{p}}\right)$ according the users' guide of the SAS software were taken. The $P_{p}$ described the influence of each factor on the target value. The global $P$ value expressed the meaning of the sum of factors on the target value. Also, the values of $\mathrm{r}^{2}$ and $P$ will be given as measures for the goodness of fit of the complete equation.

\section{RESULTS}

\section{Dynamic of ${ }^{15} \mathrm{~N}$ Enrichment in Microbial $\mathrm{N}$}

With TMR $\mathrm{O}$ and $\mathrm{P}$ (Table 1), the course of ${ }^{15} \mathrm{~N}$ enrichment in microbial $\mathrm{N}$ was studied during the entire experimental period. As shown in Figure 1, a plateau in ${ }^{15} \mathrm{~N}$ enrichment of microbial $\mathrm{N}$ was achieved within 7 $\mathrm{d}$ after starting the ${ }^{15} \mathrm{~N}$ dosage with both TMR. The course was different, however, for the 2 rations. With ration $\mathrm{P}$, which contained more ingredients and a higher energy value than ration $\mathrm{O}$, the plateau was higher and was achieved earlier than with ration $\mathrm{O}$. Based on these observations, we decided to use pooled samples of microbes from $\mathrm{d} 7$ onward in all other experiments and to consider the ${ }^{15} \mathrm{~N}$ enrichment determined in these pooled samples as the respective plateau value.

\section{Fermentation and $\mathrm{CP}_{M}$ Synthesis}

Fermentation of OM ranged from 35 to $47 \%$ (Table 3 ). A wide range was also observed for $\mathrm{CP}$ (25 to $60 \%$ ), crude fiber (10 to $30 \%$ ), NDF (3 to $28 \%$ ), ADF (6 to $23 \%$ ), and gross energy (31 to $45 \%$ ). The range in OM fermentation was not reduced when the amount of OM recovered in the nylon bags was corrected for OM from SAM (36 to 51\%; Figure 2). The $\mathrm{NH}_{3} \mathrm{~N}$ content in the liquid effluent from the vessels varied among TMR from 45 to $207 \mathrm{mg} / \mathrm{L}$ (Table 4 ).

Organic matter fermentation was not significantly correlated with ether extract content of the diet $(\mathrm{r}=$ 0.14). The CP content in TMR increased OM fermentation $(\mathrm{r}=0.79)$, and the NDF content decreased $\mathrm{OM}$ fermentation ( $r=-0.76$; Figure 3 ). Organic matter fer-
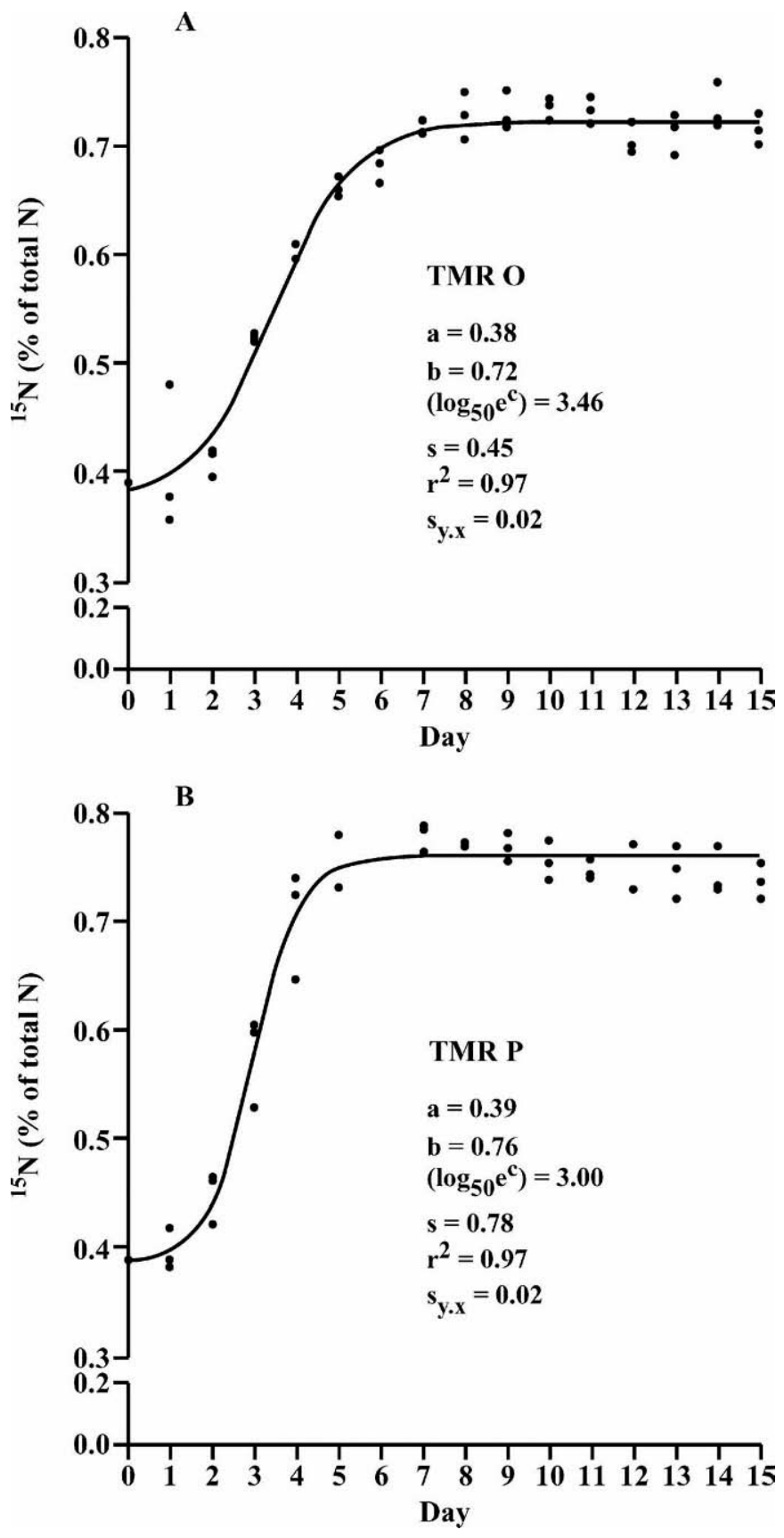

Figure 1. ${ }^{15} \mathrm{~N}$ enrichment of the microbes isolated from the effluent depending on the duration of ${ }^{15} \mathrm{~N}$ application via the buffer solution. The equation is $\mathrm{y}=\mathrm{a}+\frac{(\mathrm{b}-\mathrm{a})}{\left(1+10^{\left(\left(\log _{50} \mathrm{e}^{\mathrm{c}}-\mathrm{x}\right) \cdot \mathrm{s}\right)}\right)}$, where $\mathrm{a}=$ minimum of $y, b=$ maximum of $y, c=1 / 2$ maximum of $y$, and $s=$ maximum slope.

mentation also decreased with increasing crude fiber content $(\mathrm{r}=-0.66)$. The following multiple regression was calculated based on the variables $\mathrm{CP}, \mathrm{NDF}$, and ether extract (EE) to predict $\mathrm{OM}$ fermentation $\left(\mathrm{R}^{2}=\right.$ $0.80 ; \mathrm{CV}=4.7 \%)$ : 
Table 3. Fermented crude nutrients, NDF, ADF, and gross energy of the 16 TMR $(\% ; \mathrm{n}=3)$

\begin{tabular}{|c|c|c|c|c|c|c|c|c|c|c|c|c|}
\hline \multirow[b]{2}{*}{ TMR } & \multicolumn{2}{|c|}{$\mathrm{OM}$} & \multicolumn{2}{|c|}{$\mathrm{CP}$} & \multicolumn{2}{|c|}{$\mathrm{CF}$} & \multicolumn{2}{|c|}{$\mathrm{NDF}$} & \multicolumn{2}{|c|}{$\mathrm{ADF}$} & \multicolumn{2}{|c|}{ GE } \\
\hline & Mean & SD & Mean & SD & Mean & SD & Mean & SD & Mean & $\mathrm{SD}$ & Mean & $\mathrm{SD}$ \\
\hline A & 43.8 & 0.9 & 34.7 & 2.1 & 25.7 & 0.5 & 3.1 & 5.4 & 7.9 & 0.9 & 41.9 & 7.2 \\
\hline B & 40.5 & 0.4 & 34.4 & 0.3 & 21.1 & 1.0 & 8.0 & 1.8 & 5.5 & 4.2 & $36.7^{1}$ & \\
\hline C & 45.7 & 0.3 & 36.9 & 0.3 & 14.5 & 1.9 & 12.1 & 4.3 & 6.7 & 1.1 & $41.7^{1}$ & \\
\hline D & 44.9 & 1.2 & 39.8 & 0.7 & 11.6 & 1.5 & 8.1 & 2.6 & 9.8 & 3.8 & 38.8 & 13.3 \\
\hline $\mathrm{E}$ & 35.7 & 0.8 & 41.2 & 1.0 & 9.6 & 1.1 & 3.9 & 3.6 & 5.9 & 1.5 & 35.1 & 1.3 \\
\hline $\mathrm{F}$ & 40.3 & 0.1 & 52.5 & 0.8 & 30.0 & 1.1 & 27.8 & 0.6 & 23.4 & 0.4 & 39.6 & 0.8 \\
\hline G & 46.2 & 1.0 & 59.8 & 0.9 & 22.6 & 0.7 & 22.4 & 2.2 & 20.5 & 0.6 & 44.9 & 4.1 \\
\hline $\mathrm{H}$ & 42.2 & 0.8 & 59.9 & 0.3 & 20.9 & 2.0 & 13.6 & 2.0 & 13.6 & 4.4 & 40.4 & 2.0 \\
\hline I & 34.9 & 0.2 & 37.5 & 6.0 & 23.2 & 3.5 & 8.3 & 2.5 & 14.1 & 4.2 & 31.4 & 5.0 \\
\hline J & 38.2 & 0.5 & 36.3 & 2.0 & 29.1 & 3.5 & 15.6 & 1.9 & 12.6 & 1.3 & 36.2 & 1.9 \\
\hline K & 41.3 & 0.7 & 25.2 & 1.1 & 22.9 & 1.0 & 14.0 & 1.1 & 16.1 & 0.6 & 38.8 & 1.0 \\
\hline $\mathrm{L}$ & 39.6 & 0.5 & 38.5 & 1.8 & 13.8 & 2.3 & 12.7 & 1.5 & 7.9 & 5.3 & 37.6 & 2.3 \\
\hline $\mathrm{M}^{2}$ & 36.1 & 0.5 & 45.2 & 1.4 & 10.8 & 2.3 & 14.0 & 1.0 & 7.2 & 4.7 & 35.0 & 2.1 \\
\hline $\mathrm{N}$ & 47.3 & 1.3 & 49.5 & 1.0 & 13.1 & 2.8 & 22.3 & 0.9 & 19.3 & 1.1 & 45.4 & 2.5 \\
\hline $\mathrm{O}$ & 38.4 & 0.5 & 55.5 & 1.1 & 12.9 & 1.2 & 17.3 & 0.8 & 16.1 & 1.2 & 37.4 & 0.2 \\
\hline $\mathrm{P}$ & 41.0 & 1.0 & 34.4 & 1.2 & 18.0 & 3.2 & 24.9 & 0.9 & 17.9 & 2.1 & 38.7 & 2.2 \\
\hline
\end{tabular}

${ }^{1} \mathrm{n}=2$.

${ }^{2} \mathrm{~d} 7$ to 12 only.

$$
\begin{aligned}
\mathrm{OM}_{\mathrm{fer}}= & 33.5716 \\
& +0.0754 \times \mathrm{CP} \\
& -0.0227 \times \mathrm{NDF} \\
& +0.1060 \times \mathrm{EE}
\end{aligned}
$$

where

$$
\begin{aligned}
\mathrm{OM}_{\mathrm{fer}}= & \text { fermented } \mathrm{OM}(\%) \text { and } \mathrm{CP}, \mathrm{NDF}, \text { and } \mathrm{EE} \text { are } \\
& \text { measured in } \mathrm{g} / \mathrm{kg} \text { of DM of TMR. }
\end{aligned}
$$

The amount of $\mathrm{CP}_{\mathrm{M}}$ synthesized ranged from 677 to $1778 \mathrm{~g} / \mathrm{d}$ (Table 5). For TMR A, B, and D (Table 1),

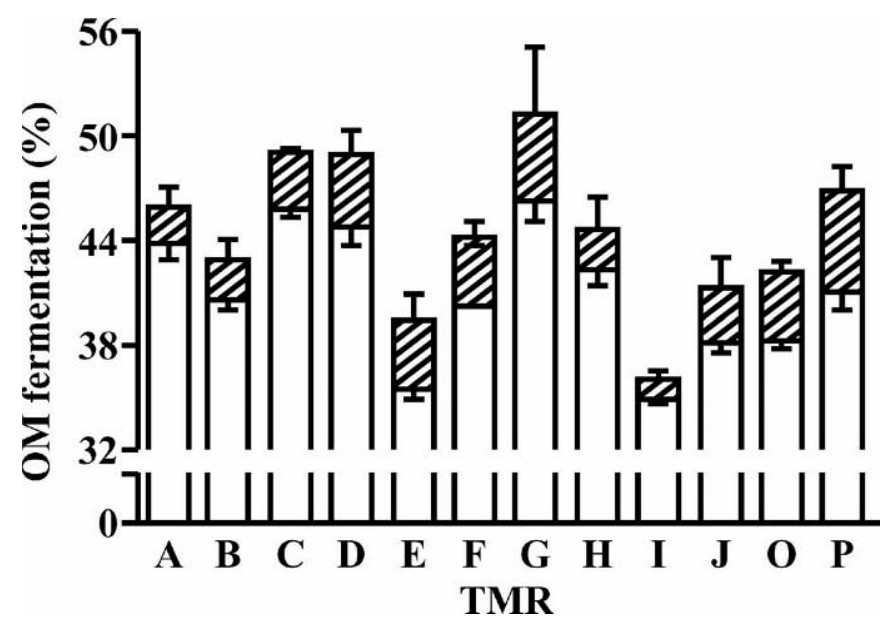

Figure 2. Comparison of OM fermentation determined either uncorrected (light bars) or under consideration of microbes associated with the feed residues taken from the nylon bags (shaded bars; mean $\pm \mathrm{SD}$ ). Rations $\mathrm{K}, \mathrm{L}, \mathrm{M}$, and $\mathrm{N}$ are not included because the ${ }^{15} \mathrm{~N}$ enrichment in residues from the nylon bags could not be determined. the $\mathrm{CP}_{\mathrm{M}}$ synthesis could not be calculated because of a shortage in the amount of effluent $\mathrm{N}$ for isotope analysis. The correlation between fermented OM and the amount of $\mathrm{CP}_{\mathrm{M}}$ synthesized/d was high ( $\mathrm{r}=0.75$; Figure 4). However, the efficiency, expressed as grams of $\mathrm{CP}_{\mathrm{M}}$ per kilogram of fermented $\mathrm{OM}$ or as grams of $\mathrm{CP}_{\mathrm{M}}$ per megajoule of ME, ranged from 141 to 286 and 4.9 to 11.1, respectively (Table 5).

\section{Regression Analysis}

Multiple regressions shown in Table 6 revealed CP and ether extract content as the variables mainly determining the efficiency of $\mathrm{CP}_{\mathrm{M}}$ synthesis expressed in

Table 4. Average $\mathrm{NH}_{3} \mathrm{~N}$ content in liquid effluent (mg/L; $\mathrm{n}=3$; means and SD)

\begin{tabular}{lrr}
\hline & \multicolumn{2}{c}{$\mathrm{NH}_{3} \mathrm{~N}$} \\
\cline { 2 - 3 } TMR & Mean & SD \\
\hline $\mathrm{A}$ & 76.6 & 0.6 \\
$\mathrm{~B}$ & 52.5 & 2.1 \\
$\mathrm{C}$ & 89.5 & 5.1 \\
$\mathrm{D}$ & 94.3 & 2.8 \\
$\mathrm{E}$ & 48.7 & 1.4 \\
$\mathrm{~F}$ & 129.5 & 3.6 \\
$\mathrm{G}$ & 201.4 & 12.3 \\
$\mathrm{H}$ & 115.5 & 9.7 \\
$\mathrm{I}$ & 45.1 & 1.6 \\
$\mathrm{~J}$ & 68.4 & 5.4 \\
$\mathrm{~K}$ & 118.3 & 6.3 \\
$\mathrm{~L}$ & 107.9 & 4.9 \\
$\mathrm{M}{ }^{1}$ & 129.7 & 9.5 \\
$\mathrm{~N}$ & 206.8 & 9.9 \\
$\mathrm{O}$ & 122.0 & 5.0 \\
$\mathrm{P}$ & 67.2 & 3.7 \\
\hline
\end{tabular}

${ }^{1} \mathrm{~d} 7$ to 12 only. 


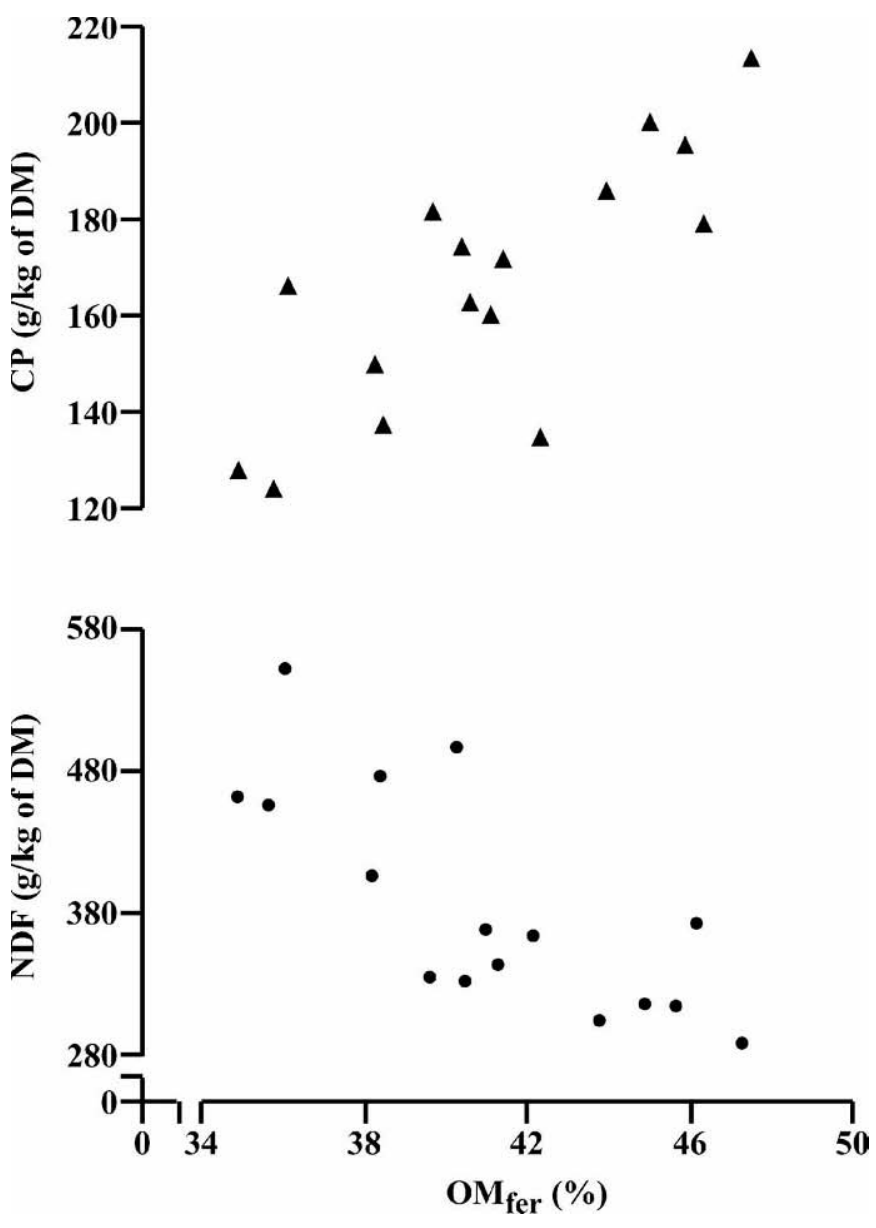

Figure 3. Relationship between fermented $\mathrm{OM}\left(\mathrm{OM}_{\text {fer }}\right)$ and $\mathrm{CP}$ and NDF content of the 16 TMR.

relation to fermented OM (regression I). The $P_{p}$ values were $<0.01$ and $=0.14$, respectively. The inclusion of $\mathrm{OM}$ and crude fiber content increased the coefficient of variation (regression II). When the dietary inclusion rate of corn silage was considered, the accuracy of the prediction improved, as judged by the coefficient of determination and the coefficient of variation (regression III). All attempts without consideration of ether extract led to higher coefficients of variation and lower coefficients of determination. When CP or corn silage inclusion rates were the considered variables alone or in combination, the accuracy of prediction was lower.

Regressions calculated to predict the efficiency of $\mathrm{CP}_{\mathrm{M}}$ synthesis in relation to $\mathrm{ME}$ are shown in Table 7. Multiple regressions again revealed $\mathrm{CP}$ and ether extract contents as the main determinants for the prediction (regression IV; $P_{p}$ values were 0.02 and 0.14 , respectively), but the accuracy of predictions based on coefficient of determination and coefficient of variation was lower than that for regression I. Including $\mathrm{OM}$ and
Table 5. Microbial CP $\left(\mathrm{CP}_{\mathrm{M}}\right)$ and efficiency of $\mathrm{CP}_{\mathrm{M}}$ synthesis $(\mathrm{n}=3)$

\begin{tabular}{|c|c|c|c|c|c|c|}
\hline \multirow[b]{2}{*}{ TMR } & \multicolumn{2}{|c|}{$\mathrm{CP}_{\mathrm{M}}$} & \multicolumn{2}{|c|}{$\mathrm{CP}_{\mathrm{M}} / \mathrm{OM}_{\mathrm{fer}}{ }^{1}$} & \multicolumn{2}{|c|}{$\mathrm{CP}_{\mathrm{M}} / \mathrm{ME}$} \\
\hline & Mean & $\mathrm{SD}$ & Mean & $\mathrm{SD}$ & Mean & $\mathrm{SD}$ \\
\hline & \multicolumn{2}{|c|}{$-(\mathrm{mg} / \mathrm{d})-$} & \multicolumn{2}{|c|}{$-(\mathrm{g} / \mathrm{kg})-$} & \multicolumn{2}{|c|}{$-(\mathrm{g} / \mathrm{MJ})-$} \\
\hline $\begin{array}{l}A^{2} \\
B^{2}\end{array}$ & & & & & & \\
\hline $\begin{array}{l}C^{3} \\
D^{2}\end{array}$ & 1,778 & & 286 & & 11.1 & \\
\hline $\mathrm{E}$ & 1,050 & 27 & 202 & 9.9 & 7.7 & 0.2 \\
\hline $\mathrm{F}$ & 1,312 & 116 & 237 & 16.0 & 8.7 & 0.8 \\
\hline G & 1,306 & 229 & 205 & 20.2 & 8.3 & 1.5 \\
\hline $\mathrm{H}$ & 984 & 77 & 165 & 8.4 & 5.9 & 0.5 \\
\hline I & 677 & 49 & 141 & 9.6 & 4.9 & 0.4 \\
\hline J & 1,012 & 82 & 188 & 8.6 & 6.3 & 0.5 \\
\hline $\mathrm{K}$ & 1,105 & 130 & 203 & 22.5 & 6.6 & 0.8 \\
\hline L & 1,070 & 94 & 202 & 19.4 & 6.7 & 0.6 \\
\hline M & 771 & 52 & 173 & 11.6 & 6.6 & 0.5 \\
\hline $\mathrm{N}$ & 1,406 & 86 & 232 & 7.9 & 8.3 & 0.5 \\
\hline $\mathrm{O}$ & 791 & 38 & 146 & 6.6 & 5.8 & 0.3 \\
\hline $\mathrm{P}$ & 1,135 & 20 & 179 & 6.2 & 6.8 & 0.1 \\
\hline Overall mean & 1,107 & & 197 & & 7.2 & \\
\hline Minimum & 677 & & 141 & & 4.9 & \\
\hline Maximum & 1,778 & & 286 & & 11.1 & \\
\hline
\end{tabular}

${ }^{1} \mathrm{OM}_{\text {fer }}=$ Microbial CP per OM fermented.

${ }^{2}$ Measurement of ${ }^{15} \mathrm{~N}$ enrichment in effluent was not possible because of shortage in sample size.

${ }^{3} \mathrm{n}=2$.

crude fiber content in the regression did not reduce the error of estimate (regression V). When OM, CP, and ether extract contents were considered, the inclusion rate of corn silage reduced the error of estimate and substantially improved the goodness of fit (regression VI). The $P_{p}$ value for the inclusion rate of corn silage was 0.15 .

\section{DISCUSSION}

For the determination of $\mathrm{CP}_{\mathrm{M}}$ synthesis, ${ }^{15} \mathrm{~N}$ has often been used as a marker for labeling the ammonia

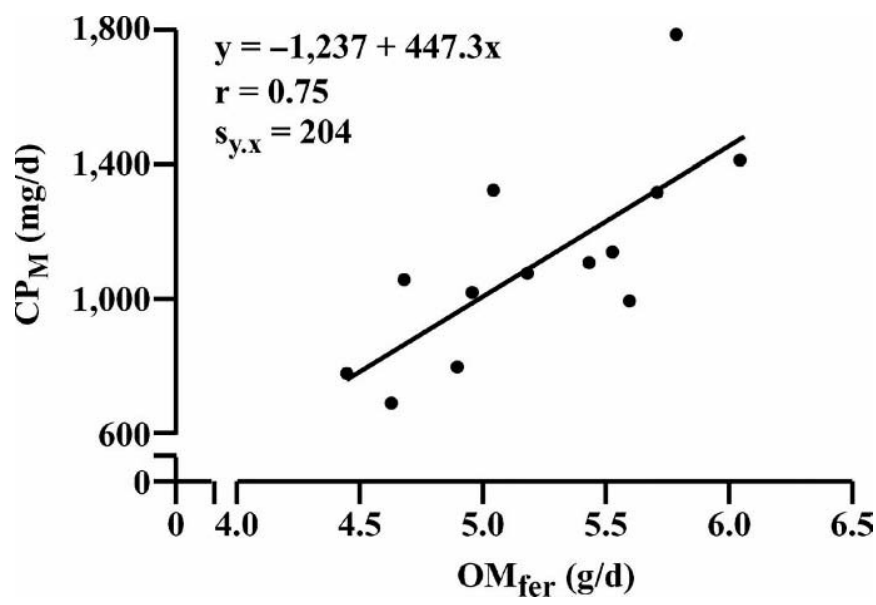

Figure 4. Relationship between fermented $\mathrm{OM}\left(\mathrm{OM}_{\mathrm{fer}}\right)$ and the amount of microbial $\mathrm{CP}\left(\mathrm{CP}_{\mathrm{M}} ; \mathrm{n}=13 \mathrm{TMR}\right)$. 
Table 6. Regressions calculated to predict the efficiency of microbial CP synthesis in relation to fermented $\mathrm{OM}$ (in $\mathrm{g} / \mathrm{kg}, \mathrm{n}=13 \mathrm{TMR}$ )

\begin{tabular}{|c|c|c|c|c|c|c|}
\hline & \multicolumn{6}{|c|}{ Regression } \\
\hline & \multicolumn{2}{|c|}{ I } & \multicolumn{2}{|c|}{ II } & \multicolumn{2}{|c|}{ III } \\
\hline & $\beta^{1}$ & $P_{p}^{2}$ & $\beta^{1}$ & $P_{p}^{2}$ & $\beta^{1}$ & $P_{p}^{2}$ \\
\hline Intercept & 9.0243 & 0.86 & -476.8325 & 0.45 & -818.9876 & 0.25 \\
\hline $\mathrm{OM}^{3}$ & & & 0.3736 & 0.49 & 0.7498 & 0.25 \\
\hline $\mathrm{CP}^{3}$ & 0.8113 & $<0.01$ & 1.2627 & 0.05 & 1.1428 & 0.07 \\
\hline Crude fiber $^{3}$ & & & 0.3641 & 0.33 & 0.3269 & 0.38 \\
\hline Ether extract ${ }^{3}$ & 1.4261 & 0.14 & 1.1370 & 0.28 & 1.2240 & 0.25 \\
\hline $\mathrm{CS}^{4}$ & & & & & 0.4720 & 0.28 \\
\hline$P_{\text {global }}$ & & 0.01 & & 0.07 & & 0.09 \\
\hline $\mathrm{R}^{2}$ & & 0.62 & & 0.68 & & 0.74 \\
\hline $\mathrm{CV}, \%$ & & 10.8 & & 11.3 & & 11.0 \\
\hline
\end{tabular}

$\mathrm{N}$ pool. Several researchers have reported that ${ }^{15} \mathrm{~N}$ and also D-alanine (Voigt et al., 1991) or purine bases (Broderick and Merchen, 1992; Calsamiglia et al., 1996; Carro and Miller, 2002) are suitable markers for determination of $\mathrm{CP}_{\mathrm{M}}$ synthesis. With regard to the in vitro approach that we used, we still had to investigate how much time was required to achieve steady-state ${ }^{15} \mathrm{~N}$ enrichment in microbial $\mathrm{N}$ after start of the ${ }^{15} \mathrm{~N}$ administration. Czerkawski and Breckenridge (1977) reported that the digestibility of DM remained constant after 4 to $6 \mathrm{~d}$ of incubation. We had assumed that the maximum ${ }^{15} \mathrm{~N}$ enrichment of microbes, using a continuous culture system, would be achieved $3 \mathrm{~d}$ after the ${ }^{15} \mathrm{~N}$ infusion started (Calsamiglia et al., 1996). It became obvious in the present study that 7 $\mathrm{d}$ of continuous ${ }^{15} \mathrm{~N}$ infusion were needed to achieve the plateau in ${ }^{15} \mathrm{~N}$ enrichment of microbes in this Rusitec system supplied with TMR (Figure 1). Sampling microbes earlier would risk an overestimation of the $\mathrm{CP}_{\mathrm{M}}$ synthesis.

The 2 TMR used for this comparison were very different in nutrient and energy contents, but basically, the course of ${ }^{15} \mathrm{~N}$ enrichment over time was similar between them. The time needed to achieve one-half of the response in ${ }^{15} \mathrm{~N}$ enrichment was about one-half of $1 \mathrm{~d}$ shorter for the higher quality TMR $\mathrm{P}$ than for TMR O. Also, the plateau was slightly higher for TMR P than for TMR O; however, the comparison suggests that the choice of TMR does not greatly affect the response to ${ }^{15} \mathrm{~N}$ administration. We concluded that a plateau in microbial $\mathrm{N}$ would be achieved for all other TMR after $7 \mathrm{~d}$ of ${ }^{15} \mathrm{~N}$ infusion.

Table 7. Regressions calculated to predict the efficiency of microbial CP synthesis in relation to ME (g/MJ; $\mathrm{n}=13$ TMR)

\begin{tabular}{|c|c|c|c|c|c|c|}
\hline & \multicolumn{6}{|c|}{ Regression } \\
\hline & \multicolumn{2}{|c|}{ IV } & \multicolumn{2}{|c|}{$\mathrm{V}$} & \multicolumn{2}{|c|}{ VI } \\
\hline & $\beta^{1}$ & $P_{p}^{2}$ & $\beta^{1}$ & $P_{p}^{2}$ & $\beta^{1}$ & $P_{p}^{2}$ \\
\hline Intercept & 0.3583 & 0.87 & 7.1045 & 0.78 & -4.1270 & 0.80 \\
\hline $\mathrm{OM}^{3}$ & & & -0.0092 & 0.68 & 0.0048 & 0.78 \\
\hline $\mathrm{CP}^{3}$ & 0.0271 & 0.02 & 0.0298 & 0.21 & 0.0192 & 0.08 \\
\hline Crude fiber ${ }^{3}$ & & & 0.0055 & 0.72 & & \\
\hline Ether extract ${ }^{3}$ & 0.0619 & 0.14 & 0.0626 & 0.16 & 0.0700 & 0.07 \\
\hline $\mathrm{CS}^{4}$ & & & & & 0.0231 & 0.15 \\
\hline$P_{\text {global }}$ & & 0.03 & & 0.10 & & 0.04 \\
\hline$R^{2}$ & & 0.53 & & 0.63 & & 0.72 \\
\hline $\mathrm{CV}, \%$ & & 12.7 & & 12.8 & & 11.1 \\
\hline
\end{tabular}


Microbial growth depends on the amount and availability of nitrogen and energy (Stern and Hoover, 1979; Hoover and Stokes, 1991); thus, $\mathrm{CP}_{\mathrm{M}}$ synthesis was expressed in relation to OM fermented in the rumen. The correlation between fermented $\mathrm{OM}$ and the amount of $\mathrm{CP}_{\mathrm{M}}$ synthesized per day was high (Figure 4). However, in comparison with other in vitro investigations (Abel et al., 1990; Mansfield et al., 1994; Carro et al., 1995; Yang et al., 2002), the extent of nutrient fermentation was low in the present study. Different factors may be responsible for such low fermentation. The fermentation of OM may be depressed when $\mathrm{N}$ is deficient for the growth of microbes (Hespell and Bryant, 1979). In the present investigation, we found a trend toward a higher fermentation of OM with increased CP supply to the vessel (Figure 3). Because most rumen bacteria prefer to use ammonia as the source of $\mathrm{N}$ for growth (Pilgrim et al., 1970; Salter et al., 1979), the degradation of feed protein may become an important factor influencing the $\mathrm{N}$ supply of microbes in this system. Ammonia concentration in the liquid effluent (Table 4), however, was not significantly correlated with $\mathrm{CP}$ content $(\mathrm{r}=0.50)$ or $\mathrm{OM}$ fermentation $(\mathrm{r}=0.55)$. It is unlikely that the amount of ammonia limited the microbial activity because a maximum microbial growth was reported for an ammonia concentration in rumen liquid between 20 and $100 \mathrm{mg} / \mathrm{L}$ (Okorie et al., 1977; Slyter et al., 1979; Pisulewski et al., 1981). For the in vitro system, Satter and Slyter (1974) estimated that an increase in ammonia concentration beyond $50 \mathrm{mg}$ of $\mathrm{NH}_{3} \mathrm{~N} / \mathrm{L}$ in liquid effluent had no effect on the $\mathrm{CP}_{\mathrm{M}}$ synthesis. Their data suggest, however, that the limiting concentration is closer to $20 \mathrm{mg}$ of $\mathrm{NH}_{3} \mathrm{~N} / \mathrm{L}$. In our study, in no case was the concentration $<45 \mathrm{mg}$ of $\mathrm{NH}_{3} \mathrm{~N} /$ L (Table 4).

Furthermore, the relatively high $\mathrm{pH}$ values (6.9 to $7.3)$ and the low flow rate of artificial saliva $(565 \mathrm{~mL} /$ $\mathrm{d} ; \mathrm{SD}=24$ ) are not in line with the observed low level of nutrient fermentation. Some researchers have suggested that a high $\mathrm{pH}$ promotes the degradation of $\mathrm{OM}$ (Grant and Weidner, 1992; Calsamiglia et al., 2002; Yang et al., 2002) and that the degradation of DM was not affected within a wide range of dilution rate (Czerkawski and Breckenridge, 1977). Even the chosen pore size of $100 \mu \mathrm{m}$ can be expected to have a positive effect on the degradation of DM and NDF when compared with 40 or $200 \mu \mathrm{m}$ (Carro et al., 1995).

Perhaps the postincubation washing and squeezing procedure contributed to the differences in fermentation rate compared with other studies; these procedures may affect the loss of small feed particles from the bag. Also, microbes attached to feed particles could cause an underestimation of fermentation; however, the correction of OM fermentation for SAM could also not ex- plain the low level of OM fermentation. Figure 2 shows that the extent of fermentation of OM was only between 1.2 and $6.0 \%$ higher after correction for SAM. The percentage of OM in feed residues originating from SAM amounted to at least $2 \%$.

High variation in efficiency of the $\mathrm{CP}_{\mathrm{M}}$ synthesis has often been described both in vivo (Armstrong, 1980) and in vitro (Abel et al., 1990; Calsamiglia et al., 1995; Bach et al., 1999; Carro and Miller, 1999; Colombatto et al., 2003). Factors that contribute to this variation are the feedstuffs used, their chemical composition, and the amount of feed, as well as the microbial population in the rumen (Armstrong, 1980). Many interrelations make it difficult to systematically investigate single factors with regard to their effects on microbial activity. In the present study, it appears that CP content of TMR was an important factor determining the amount of $\mathrm{CP}_{\mathrm{M}}$ per unit of fermented OM (Table 6). Both the $\mathrm{N}$ content in the ration and the availability of $\mathrm{N}$ and energy are decisive for $\mathrm{CP}_{\mathrm{M}}$ synthesis. The use of TMR enables an optimization of ruminal digestion because different sources of $\mathrm{N}$ and carbohydrates with different kinetics of degradation are offered at the same time. Moreover, the TMR used in this work contained between 12 and $21 \%$ CP in DM. According to Kluth et al. (2000), in this range of dietary CP content, no effect on the $\mathrm{N}$ balance in the rumen on efficiency of $\mathrm{CP}_{\mathrm{M}}$ synthesis can be expected. Therefore, we conclude that the content and availability of $\mathrm{N}$ were not the limiting factors in the present study. This conclusion is supported by the lack of correlation between ammonia concentration in the system and OM fermentation as discussed previously. Demeyer and Fievez (2004) argued that the synthesis of rumen bacterial protein may be limited by amino acid supply in the rumen at high production levels and that the optimization of bacterial protein production may require knowledge of the nature of the limiting free amino acids. Under in vivo conditions, free amino acids are generally contained in rumen fluid only in low concentrations (Wallace, 1996). Nevertheless, it turned out in in vitro studies that some AA are essential for bacteria (Atasoglu et al., 2001, 2004) and that the growth of microbes can be promoted by supplementation of peptides or AA (Maeng et al., 1975; Argyle and Baldwin, 1989; Griswold et al., 1996; Kajikawa et al., 2002). Along this line, the CP effect on efficiency of $\mathrm{CP}_{\mathrm{M}}$ synthesis may be caused by the supply of certain (limiting) amino acids by the TMR.

The supplementation of lipids caused a decrease in ruminal degradation (Palmquist and Jenkins, 1980; Jenkins and Fotouhi, 1990). Abel et al. (1990) and Doreau et al. (1991) reported only small effects of fat supplementation on the fermentation of nutrients; however, the equations determined in this study indicate that 
a higher content of $\mathrm{EE}$ increased the amount of $\mathrm{OM}$ fermented and also increased the efficiency of $\mathrm{CP}_{\mathrm{M}}$ synthesis. This finding is in agreement with Jenkins and Fotouhi (1990), who reported that adding fat increased the efficiency of microbial yield.

Another factor that was identified as important for $\mathrm{CP}_{\mathrm{M}}$ synthesis was the inclusion rate of corn silage in TMR (Table 6). In vivo studies have indicated that higher inclusion rates of corn silage in mixed rations increased the efficiency of $\mathrm{CP}_{\mathrm{M}}$ synthesis, but the different inclusion rates were not taken into account (Givens and Rulquin, 2004). The efficiency in rations based on grass silage is reduced, probably as a consequence of rapid and asynchronous release of $\mathrm{N}$ relative to energy from carbohydrates (Siddons et al., 1985). In the present study, a significant monofactorial relationship between the efficiency of $\mathrm{CP}_{\mathrm{M}}$ synthesis and the inclusion rate of corn silage was not observed $(\mathrm{r}=-0.26)$; however, the goodness of fit in multiple regression analysis could be improved by additional consideration of the maize silage inclusion rate in the regressions (Tables 6 and 7).

The efficiencies expressed in relation to $\mathrm{ME}$ as shown in Table 5 are on a lower level than data from studies with dairy cows (Gesellschaft für Ernährungsphysiologie, 2001), but they are difficult to interpret and to compare with in vivo data. First, $\mathrm{CP}_{\mathrm{M}}$ was determined in vitro, and $\mathrm{ME}$ was calculated based on the digestibilities determined in standardized wether trials. Second, a comparison between the rumen and the Rusitec system must be made with care. The number of protozoa is extremely reduced in rumen simulation systems (Mansfield et al., 1995), and it is also possible that the bacterial population changes in comparison with the natural rumen (Slyter and Putnam, 1967). Feed is enclosed in nylon bags in the Rusitec, which may affect accessibility for microbes. Differences between fermentation in continuous culture and in vivo may also arise because of a lack of $\mathrm{N}$ recycling and absorption for products of metabolism, respectively (Mansfield et al., 1995); however, the degradation of $\mathrm{OM}, \mathrm{CP}$, and amino acids did not differ between dairy cows and a continuous rumen simulation system in the study of Hannah et al. (1986). Also, short-term studies with a modified, semicontinuous Rusitec in comparison with a natural rumen did not show significant differences in the fermentation, the concentration of short-chain fatty acids, and the number of microbes (Gizzi et al., 1998). Passage rates of fluid and feed, $\mathrm{pH}$ in the vessel, amount of feed per day, and the method of separation of microbes representing the total population are critical points in such comparisons and make it difficult to draw conclusions that apply to the feeding of cows.

\section{CONCLUSIONS}

In vitro fermentation of OM from TMR depends on the contents of $\mathrm{CP}$ and NDF in the ration. The $\mathrm{CP}_{\mathrm{M}}$ synthesis correlated with OM fermentation. Regression analysis did not identify dietary factors that can clearly explain the high variation in the efficiency of $\mathrm{CP}_{\mathrm{M}}$ synthesis; however, among the factors studied, CP and ether extract content as well as the inclusion rate of corn silage in the ration helped to explain part of the variation. When ${ }^{15} \mathrm{~N}$ is used as a marker to study microbial growth in a Rusitec system fed with TMR, $7 \mathrm{~d}$ of continuous ${ }^{15} \mathrm{~N}$ infusion are needed to achieve the steady-state enrichment in microbial N. Sampling of microbes for ${ }^{15} \mathrm{~N}$ analysis should not start prior to this time.

\section{ACKNOWLEDGMENT}

This study was supported by the Studienstiftung des Deutschen Volkes with a doctoral scholarship for Jeannette Boguhn, which is gratefully acknowledged.

\section{REFERENCES}

Abel, H., G. Coenen, and I. Immig. 1990. Investigations on the effects of fat and starch supplementations on microbial metabolism in a rumen simulation system RUSITEC. J. Anim. Physiol. Anim. Nutr. 64:62-73.

Aldrich, J. M., L. D. Muller, and G. A. Varga. 1993. Nonstructural carbohydrate and protein effects on rumen fermentation, nutrient flow, and performance of dairy cows. J. Dairy Sci. 76:1091-1105.

Argyle, J. L., and R. L. Baldwin. 1989. Effects of amino acids and peptides on rumen microbial growth yields. J. Dairy Sci. 72:2017-2027.

Armstrong, D. G. 1980. Net efficiences (in vivo) of microbial N synthesis in ruminant livestock. Pages 400-413 in Proc. 3rd EAAP Symp. Protein Metabolism and Nutrition, Braunschweig. EAAP Publication No. 27. H. J. Oslage and K. Rohr, ed. Institut für Tierernährung, FAL, Braunschweig-Völkenrode, Germany.

Atasoglu, C., A. Y. Guliye, and R. J. Wallace. 2004. Use of stable isotopes to measure de novo synthesis and turnover of amino acid-C and - $\mathrm{N}$ in mixed micro-organisms from the sheep rumen in vitro. Br. J. Nutr. 91:253-261.

Atasoglu, C., C. J. Newbold, and R. J. Wallace. 2001. Incorporation of $[15 \mathrm{~N}]$ ammonia by the cellulolytic ruminal bacteria Fibrobacter succinogenes BL2, Ruminococcus albus SY3, and Ruminococcus flavefaciens 17. Appl. Environ. Microbiol. 67:2819-2822.

Ausschuss für Bedarfsnormen. 1991. Leitlinien für die Bestimmung der Verdaulichkeit von Rohnährstoffen an Wiederkäuern. J. Anim. Physiol. Anim. Nutr. 65:229-234.

Bach, A., I. K. Yoon, M. D. Stern, H. G. Jung, and H. Chester-Jones. 1999. Effects of type of carbohydrate supplementation to lush pasture on microbial fermentation in continuous culture. J. Dairy Sci. 82:153-160.

Boguhn, J., H. Kluth, O. Steinhöfel, M. Peterhänsel, and M. Rodehutscord. 2003. Nutrient digestibility and prediction of metabolizable energy in total mixed rations for ruminants. Arch. Anim. Nutr. 57:253-266.

Brandt, M., and K. Rohr. 1981. Beiträge zur Quantifizierung der NUmsetzungen in den Vormägen von Milchkühen 1. Mitteilung: Bestimmung des Mikrobenstickstoffs im Duodenalchymus mit Hilfe von $15 \mathrm{~N}$. Z. Tierphysiol. Tierernahr. Futtermittelkd. 46:39-48. 
Broderick, G. A., and N. R. Merchen. 1992. Markers for quantifying microbial protein synthesis in the rumen. J. Dairy Sci. 75:2618-2632.

Bulang, M., J. Boguhn, T. Engelhard, H. Kluth, and M. Rodehutscord. 2004. Studies with alfalfa silage as a forage source for high yielding dairy cows. Proc. Soc. Nutr. Physiol. 13:96. (Abstr.)

Calsamiglia, S., A. Ferret, and M. Devant. 2002. Effects of pH and $\mathrm{pH}$ fluctuations on microbial fermentation and nutrient flow from a dual-flow continuous culture system. J. Dairy Sci. 85:574-579.

Calsamiglia, S., M. D. Stern, and J. L. Firkins. 1995. Effects of protein source on nitrogen metabolism in continuous culture and intestinal digestion in vitro. J. Anim. Sci. 73:1819-1827.

Calsamiglia, S., M. D. Stern, and J. L. Firkins. 1996. Comparison of nitrogen-15 and purines as microbial markers in continuous culture. J. Anim. Sci. 74:1375-1381.

Carro, M. D., P. Lebzien, and K. Rohr. 1995. Effects of pore size of nylon bags and dilution rate on fermentation parameters in a semi-continuous artificial rumen. Small Rumin. Res. 15:113-119.

Carro, M. D., and E. L. Miller. 1999. Effect of supplementing a fibre basal diet with different nitrogen forms on ruminal fermentation and microbial growth in an in vitro semi-continuous culture system (RUSITEC). Br. J. Nutr. 82:149-157.

Carro, M. D., and E. L. Miller. 2002. Comparison of microbial markers (15N and purine bases) and bacterial isolates for the estimation of rumen microbial protein synthesis. Anim. Sci. 75:315-321.

Chamberlain, D. G., and P. C. Thomas. 1979. Ruminal nitrogen metabolism and the passage of amino acids to the duodenum in sheep receiving diets containing hay and concentrates in various proportions. J. Sci. Food Agric. 30:677-686.

Clark, J. H. 1975. Lactational responses to postruminal administration of protein and amino acids. J. Dairy Sci. 58:1178-1197.

Coenen, M. 1996. Mischrationen, Total mixed ration, eine Fütterungstechnik aus tierärztlicher Sicht. Übers. Tierernährg. 24:118128.

Colombatto, D., G. Hervás, W. Z. Yang, and K. A. Beauchemin. 2003. Effects of enzyme supplementation of a total mixed ration on microbial fermentation in continuous culture, maintained at high and low pH. J. Anim. Sci. 81:2617-2627.

Czerkawski, J. W., and G. Breckenridge. 1977. Design and development of a long-term rumen simulation technique (Rusitec). Br. J. Nutr. 38:371-384.

Czerkawski, J. W., and G. Breckenridge. 1985. Metabolism of protein supplements studied by rumen simulation technique (Rusitec). Arch. Tierern. 35:261-277.

Demeyer, D., and V. Fievez. 2004. Invited commentary: Is the synthesis of rumen bacterial protein limited by the availability of preformed amino acids and/or peptides? Br. J. Nutr. 91:175-176.

Doreau, M., F. Legay, and D. Bauchart. 1991. Effect of source and level of supplemental fat on total and ruminal organic matter and nitrogen digestion in dairy cows. J. Dairy Sci. 74:2233-2242.

Gesellschaft für Ernährungsphysiologie. 1995. Mitteilungen des Ausschusses für Bedarfsnormen: Zur Energiebewertung beim Wiederkäuer. Proc. Soc. Nutr. Physiol. 4:121-123.

Gesellschaft für Ernährungsphysiologie. 2001. Empfehlungen zur Energie- und Nährstoffversorgung der Milchkühe und Aufzuchtrinder. DLG Verlags GmbH, Frankfurt/Main, Germany.

Givens, D. I., and H. Rulquin. 2004. Utilisation by ruminants of nitrogen compounds in silage-based diets. Anim. Feed Sci. Technol. 114:1-18.

Gizzi, G., R. Zanchi, and F. Sciaraffia. 1998. Comparison of microbiological and fermentation parameters obtained with an improved rumen in vitro technique with those obtained in vivo. Anim. Feed Sci. Technol. 73:291-305.

Grant, R. J., and S. J. Weidner. 1992. Digestion kinetics of fiber: Influence of in vitro buffer $\mathrm{pH}$ varied within observed physiological range. J. Dairy Sci. 75:1060-1068.

Griswold, K. E., W. H. Hoover, T. K. Miller, and W. V. Thayne. 1996. Effect of form of nitrogen on growth of ruminal microbes in continuous culture. J. Anim. Sci. 74:483-491.

Hannah, S. M., M. D. Stern, and F. R. Ehle. 1986. Evaluation of a dual flow continuous culture system for estimating bacterial fermentation in vivo of mixed diets containing various soya bean products. Anim. Feed Sci. Technol. 16:51-62.

Herrera-Saldana, R., R. Gomez-Alarcon, M. Torabi, and J. T. Huber. 1990. Influence of synchronizing protein and starch degradation in the rumen on nutrient utilization and microbial protein synthesis. J. Dairy Sci. 73:142-148.

Hespell, R. B., and M. P. Bryant. 1979. Efficiency of rumen microbial growth: Influence of some theoretical and experimental factors on Y ATP. J. Anim. Sci. 49:1640-1659.

Hoover, W. H., and S. R. Stokes. 1991. Balancing carbohydrates and protein for optimum rumen microbial yield. J. Dairy Sci. 74:3630-3644.

Hristov, A. N., and G. A. Broderick. 1996. Synthesis of microbial protein in ruminally cannulated cows fed alfalfa silage, alfalfa hay, or corn silage. J. Dairy Sci. 79:1627-1637.

Jenkins, T. C., and N. Fotouhi. 1990. Effects of lecithin and corn oil on site of digestion, ruminal fermentation and microbial protein synthesis in sheep. J. Anim. Sci. 68:460-466.

Kajikawa, H., M. Mitsumori, and S. Ohmomo. 2002. Stimulatory and inhibitory effects of protein amino acids on growth rate and efficiency of mixed ruminal bacteria. J. Dairy Sci. 85:2015-2022.

Kang-Meznarich, J. H., and G. A. Broderick. 1981. Effects of incremental urea supplementation on ruminal ammonia concentration and bacterial protein formation. J. Anim. Sci. 51:422-431.

Kluth, H., T. Engelhard, and M. Rodehutscord. 2005. Zum Ersatz von Sojaextraktionsschrot durch Rapsextraktionsschrot in der Fütterung der Hochleistungskuh. Züchtungskunde. 77:58-70.

Kluth, H., M. Gabel, J. Voigt, and U. Schönhusen. 2000. The use of endogenous nitrogen for microbial crude protein synthesis in the rumen of growing bulls. J. Anim. Physiol. Anim. Nutr. 84:136147.

Madsen, J., and T. Hvelplund. 1988. The influence of different protein supply and feeding level on $\mathrm{pH}$, ammonia concentration and microbial protein synthesis in the rumen of cows. Acta Agric. Scand. 38:115-125.

Maeng, W. J., C. J. van Nevel, R. L. Baldwin, and J. G. Morris. 1975. Rumen microbial growth rates and yields: Effect of amino acids and protein. J. Dairy Sci. 59:68-79.

Mansfield, H. R., M. I. Endres, and M. D. Stern. 1994. Influence of non-fibrous carbohydrate and degradable intake protein on fermentation by ruminal microorganisms in continuous culture. J. Anim. Sci. 72:2464-2474.

Mansfield, H. R., M. I. Endres, and M. D. Stern. 1995. Comparison of microbial fermentation in the rumen of dairy cows and dual flow continuous culture. Anim. Feed Sci. Technol. 55:47-66.

McDougall, E. I. 1948. Studies on ruminant saliva. 1. The composition and output of sheep's saliva. Biochem. J. 43:99-109.

Minato, H., and T. Suto. 1978. Technique for fractionation of bacteria in rumen microbial ecosystem. II. Attachment of bacteria isolated from bovine rumen to cellulose powder in vitro and elution of bacteria attached therefrom. J. Gen. Appl. Microbiol. 24:1-16.

Naumann, C., and R. Bassler. 1976. VDLUFA-Methodenbuch, Vol. III. Die chemische Untersuchung von Futtermitteln. Loose leaflet collection with supplements from 1983, 1988, 1993, and 1997. VDLUFA-Verlag, Darmstadt, Germany.

NRC. 2001. Protein and amino acids. Pages 43-104 in Nutrient Requirements of Dairy Cattle. Natl. Acad. Press, Washington, DC.

Okorie, A. U., P. J. Buttery, and D. Lewis. 1977. Ammonia concentration and protein synthesis in the rumen. Proc. Nutr. Soc. 36:38A.

Palmquist, D. L., and T. C. Jenkins. 1980. Fat in lactation rations: A review. J. Dairy Sci. 63:1-14.

Petri, A., H. Müschen, G. Breves, O. Richter, and E. Pfeffer. 1988. Response of lactating goats to low phosphorus intake. 2. Nitrogen transfer from rumen ammonia to rumen microbes and proportion of milk protein derived from microbial amino acids. J. Agric. Sci. (Camb.) 111:265-271.

Pilgrim, A. F., F. V. Gray, R. A. Weller, and C. B. Belling. 1970. Synthesis of microbial protein from ammonia in sheep's rumen and the proportion of dietary converted into microbial nitrogen. Br. J. Nutr. 24:589-598. 
Pisulewski, P. M., A. U. Okorie, P. J. Buttery, W. Haresign, and D. Lewis. 1981. Ammonia concentration and protein synthesis in the rumen. J. Sci. Food Agric. 32:759-766.

Salter, D. N., K. Daneshar, and R. H. Smith. 1979. The origin of nitrogen incorporated into compounds in the rumen bacteria of steers given protein- and urea-containing diets. Br. J. Nutr. 41:197-209.

Satter, L. D., and L. L. Slyter. 1974. Effect of ammonia concentration on rumen microbial protein production in vitro. Br. J. Nutr. $32: 199-208$

Siddons, R. C., J. V. Nolan, D. E. Beever, and J. C. Macrae. 1985. Nitrogen digestion and metabolism in sheep consuming diets containing contrasting forms and levels of N. Br. J. Nutr. 54:175-187.

Sinclair, L. A., P. C. Garnsworthy, J. R. Newbold, and P. J. Buttery. 1993. Effect of synchronizing the rate of dietary energy and nitrogen release on rumen fermentation and microbial protein synthesis in sheep. J. Agric. Sci. (Camb.) 120:251-263.

Slyter, L. L., and P. A. Putnam. 1967. In vivo vs. in vitro continuous culture of ruminal microbial populations. J. Anim. Sci. $26: 1421-1424$.

Slyter, L. L., L. D. Satter, and D. A. Dinius. 1979. Effect of ruminal ammonia concentration on nitrogen utilization by steers. J. Anim. Sci. 48:906-912.

Stern, M. D., and W. H. Hoover. 1979. Methods for determining and factors affecting rumen microbial protein synthesis: A review. J. Anim. Sci. 49:1590-1603

Stokes, S. R., W. H. Hoover, T. K. Miller, and R. P. Manski. 1991. Impact of carbohydrate and protein levels on bacterial metabolism in continuous culture. J. Dairy Sci. 74:860-870.

Sutton, J. D., S. B. Cammell, R. H. Phipps, D. E. Beever, and D. J. Humphries. 2000. The effect of crop maturity on the nutritional value of maize silage for lactating dairy cows 2 . Ruminal and post-ruminal digestion. Anim. Sci. 71:391-400.

van Es, A. J. H. 1978. Feed evaluation for ruminants. I. The systems in use from May 1977 onwards in the Netherlands. Livest. Prod. Sci. 5:331-345.

Veira, D. M., G. K. Macleod, J. H. Burton, and J. B. Stone. 1980. Nutrition of the weaned holstein calf. I. Effect of the dietary protein level on rumen metabolism. J. Anim. Sci. 50:937-944.

Verbiè, J., E. R. Ørskov, J. Žgajnar, X. B. Chen, and V. ŽnidaršièPongrac. 1999. The effect of method of forage preservation on the protein degradability and microbial protein synthesis in the rumen. Anim. Feed Sci. Technol. 82:195-212.

Voigt, J., U. Schönhusen, R. Krawielitzki, and B. Piatkowski. 1991. Comparison of $15 \mathrm{~N}$, amino acid profile, RNA, DAP and D-Alanin as markers for microbial nitrogen flowing to the duodenum of dairy cows. Pages 71-73 in Proc. 6th Int. Symp. Protein Metabolism and Nutrition, Herning, Denmark, EAAP Publication No. 59. B. O. Eggum, S. Boisen, C. Børsting, A. Danfœr, and T. Hvelplund, ed. National Institute of Animal Science, Foulum, Denmark.

Wallace, R. J. 1996. Ruminal microbial metabolism of peptides and amino acids. J. Nutr. 126:1326S-1334S.

Wright, T. C., S. Moscardini, P. H. Luimes, P. Susmel, and B. W McBride. 1998. Effects of rumen-undegradable protein and feed intake on nitrogen balance and milk protein production in dairy cows. J. Dairy Sci. 81:784-793.

Yang, W. Z., K. A. Beauchemin, and D. D. Vedres. 2002. Effects of $\mathrm{pH}$ and fibrolytic enzymes on digestibility, bacterial protein synthesis, and fermentation in continuous culture. Anim. Feed Sci. Technol. 102:137-150.

Younge, B. A., J. J. Murphy, and M. Rath. 2004. Nutrient metabolism in the rumen and milk production in cows fed on grass-silage and fresh grass based diets. Livest. Prod. Sci. 88:43-54. 